\title{
Perlindungan Anak Buruh Migran di Kabupaten Cirebon (Analisis Terhadap Konsep Dampak Anak yang Ditinggalkan)
}

\author{
Suryadi \\ suryadie.aj@gmail.com
}

\begin{abstract}
ABSTRACK
Migration is a natural process of human population dynamics that move from place to place for a wide variety of orientations. The phenomenon of international migration is often an overview of the economic situation of a country in equality. Child is the mandate of Almighty God, in their houlders the future of the family, the nation and the state will be handled. Therefore the completion of their optimal growth and development is the duty of the parents and all community elements, including the state to participate in its favor. Child Rights and Protection Act (UUPA) is a manifestation of the seriousness of the state in implementatng the ringhts of the children while protecting them from potential violence that is always threatening. The phenomenon of migrant workers makes children face problem by lack of primary escort their growth process, especially the mother. The role of the father or mother became the sole companion of children and family members assisted potentially unable to meet the data protection and rights of children. Based on the survey results in general the proportion of the fulfillment of 4 (four) children's fundamental rights, namely the right to life, growng rights, protection rights and the rights of the opinion can be met by one if his parents or both become migrant workers. In the midst of the stuggle to fulfillment of social and economic needs by migrant workers, beside economic pressures and the exsistence of self in community life, international migration is a quick way to meet all needs, most sources person said needs serious attention to the problems of migrant workers children, by optimizing the existence of regulation with the synegy and policies and programs by both government and non-government organizations and community.
\end{abstract}

Keyword: migrant workers, the rights and protection of children.

\section{A. Latar Belakang}

Membahas permasalahan buruh migran Indonesia, seperti mencari jarum dalam jerami. Perumpamaan tersebut untuk menggambarkan betapa rumit permasalahan yang melingkupinya. Permasalahan buruh migran tidak hanya berkaitan dengan mobilitas penduduk ke luar negeri untuk mencari nilai lebih di negara tujuan. Di balik proses mobilitas penduduk, keadaan itu menggambarkan kondisi negara yang belum mampu menyediakan lapangan pekerjaan bagi warganya di dalam negeri. Kondisi tersebut sebagai salah satu faktor pendorong mobilitas pekerja ke luar negeri. Negara dapat dikatakan gagal dalam menyediakan lapangan pekerjaan 
bagi warga negara sehingga menyebabkan banyak dari warga negaranya terpaksa mengadu nasib ke luar negeri baik dengan cara legal, namun tidak sedikit pula karena persyaratan yang rumit dan mahal, para calon TKI memilih jalan yang ilegal. Perlindungan bagi sang devisator negara pun terlalaikan, terlihat dari banyaknya kasus yang dialami oleh Buruh Migran asal Indonesia. Mulai dari dipulangkan karena tertipu agensi, disiksa, diperkosa, diperjualbelikan, ditembak, dipancung, dan bahkan dihukum mati.

Di samping itu, risiko lainnya adalah potensi munculnya permasalahan pada keluarga yang ditinggalkan oleh TKI, khususnya pada anak-anak. Karena mereka secara psikologis ada dalam fase tumbuh dan berkembang yang membutuhkan perhatian dan bimbingan dari orang tua. Sebagaimana disebutkan dalam Undang-Undang Nomor 4 Tahun 1979 Tentang Kesejahteraan Anak dalam pasal 1, ayat 1, (a) Kesejahteraan Anak adalah suatu tata kehidupan dan penghidupan anak yang dapat menjadi pertumbuhan dan perkembangannya dengan wajar, baik secara rohani, jasmani maupun sosial; (b) Usaha Kesejahteraan anak dalam usaha kesejahteraan sosial yang ditujukan untuk menjamin terwujudnya Kesejahteraan Anak terutama terpenuhinya kebutuhan pokok anak.

Demikian juga senada disampaikan dalam Undang-Undang Nomor 23 Tahun 2002 Tentang Perlindungan Anak, pasal 1 yang berbunyi: (1) Anak adalah seorang yang belum berusia 18 (delapan belas) tahun, termasuk anak yang masih dalam kandungan, (2) Perlindungan anak adalah segala kegiatan untuk menjamin dan melindungi anak dan hak-haknya agar dapat hidup, tumbuh, berkembang, dan berpartisipasi, secara optimal sesuai dengan harkat dan martabat kemanusiaan, serta mendapat perlindungan dari kekerasan diskriminasi.

Berdasarkan data yang dirilis oleh BNP2TKI dalam penempatan TKI ke luar negeri tahun 2014 terdapat sebanyak 429.872, dari jumlah tersebut Jawa Barat sebanyak 105,479 orang. Sedangkan untuk kabupaten Lombok Timur merupakan Kabupaten tertinggi dari 25 kabupaten terbesar penyumbang penempatan TKI, yaitu sebanyak 29,510 orang. Berturut-turut berikutnya adalah Kabupaten Indramayu 25.521, Cilacap 16.013, Cirebon 15.786, dan Lombok Tengah 14.109.

Kabupaten Cirebon menempati urutan ke-empat kota/kabupaten tertinggi pengirim buruh migran ke luar negeri. Mobilitas buruh migran ke luar negeri tentu memiliki implikasi yang cukup penting berkaitan dengan keluarga yang ditinggalkan di daerah asal. Anak-anak merupakan kelompok paling rentan yang akan menerima dampak langsung dari orang tua mereka sebagai buruh migran. Terlebih lagi data BNP2TKI menunjukkan bahwa tenaga kerja wanita (TKW) yang pergi bekerja ke luar negeri lebih besar daripada tenaga kerja laki-laki. Pada tahun 2011 sebanyak sekitar 377 ribu (64\%) TKW yang menjadi buruh migran sedangkan sedangkan tenaga kerja lakilaki ada sekitar 210 ribu (36\%) yang bekerja ke luar negeri. Nampak sekali proporsi TKW lebih besar dibandingkan dengan tenaga kerja laki-laki mengingat kebutuhan penempatan di negara tujuan lebih besar tenaga kerja perempuan.

Pada tahun 2012 proporsi TKW adalah 57 persen (279.784) dan tenaga kerja laki-laki 43 persen (214.825), berikutnya tahun 2013 proporsi TKW sebanyak 54 persen dan tenaga kerja lakilaki sebanyak 46 persen. Data tersebut mengungkapkan fakta bahwa proporsi perempuan yang masuk ke ranah publik 
ke luar negeri lebih besar dibandingkan laki-laki. Akan tetapi jika kembali dilihat jenis pekerjaan yang paling banyak diserap di pasar kerja luar negeri kita akan tercengang karena proporsi terbesar mereka adalah sebagai pekerja rumah tangga (domestic worker), kemudian sebagai perawat lansia atau anak (caregiver) dan disusul dengan pekerjaan sebagai pekerja perkebunan (plantation worker).

Perginya orang tua ke luar negeri, khususnya ibu memiliki pengaruh dalam banyak dimensi karena mereka dalam fase psikologis tumbuh dan perkembangan yang memerlukan dampingan dari keluarga, khususnya orang tua yaitu ibu dan bapak. Rossi (2008) dalam Demurger dan Xu (2013) mengungkapkan secara serius potensi masalah yang diakibatkan oleh orang tua yang meninggalkan anak sebagai buruh migran potensial menjadi biaya sosial, di samping yang diperoleh :

"leaving children behind is a source of a potentially high "social cost of migration", althought migration may also confer benefits to the left-behind family through remittance transfers that relax budget constraints and thereby increasi health and education opportunities."

\section{B. Permasalahan}

Berdasarkan permasalahan yang telah dipaparkan pada bagian terdahulu, perlu kiranya diketahui lebih mendalam terkait beberapa variabel perlindungan anak buruh migran di Kabupaten Cirebon, meliputi sebagai berikut:

1. Bagaimana karakter demografis, sosial, dan ekonomi keluarga buruh migran di Kabupaten Cirebon?

2. Bagaimana implementasi hak anak buruh migran di Kabupaten Cirebon?

3. Bagaimana persepsi masyarakat tentang perlunya regulasi dan perlindungan anak buruh migran di Kabupaten Cirebon?

C. Kajian Teori dan Konsep

1. Teori Migrasi dan Konsep Dampak Anak Yang Ditinggalkan (Child leftBehind)

Menurut Everett S. Lee (1996) dalam Rozy Munir mengatakan empat faktor yang menyebabkan orang mengambil keputusan untuk melakukan migrasi yaitu:

1. Faktor-faktor yang terdapat di daerah asal

2. Faktor-faktor yang terdapat di daerah tujuan

3. Rintangan-rintangan yang menghambat

4. Faktor-faktor pribadi

Teori tersebut selalu beriringan dengan konsep khusus migrasi internasional yang saat ini telah menjadi sama penting dalam pembangunan ekonomi di negara berkembang, termasuk Indonesia. Makin terbukanya kesempatan kerja antarnegara menyebabkan tenaga kerja dapat dengan mudah keluar masuk di pasar tenaga kerja internasional. Dengan bekerja di luar negeri, secara otomatis tenaga kerja akan berstatus menjadi migran internasional. Saat ini, sebanyak 232 juta atau 2,3\% dari total populasi dunia berstatus migran internasional (World Bank, 2013).

Pengertian dampak menurut Kamus Besar Bahasa Indonesia adalah benturan, pengaruh yang mendatangkan akibat baik positif maupun negatif. Pengaruh adalah daya yang ada dan timbul dari sesuatu (orang, benda) yang ikut membentuk watak, kepercayaan atau perbuatan seseorang. Pengaruh adalah suatu keadaan di mana ada hubungan timbal balik atau hubungan sebab akibat antara apa yang mempengaruhi dengan apa yang dipengaruhi. (KBBI Online) 
Dampak secara sederhana bisa diartikan sebagai pengaruh atau akibat. Setiap keputusan yang diambil oleh seseorang biasanya mempunyai dampak tersendiri, baik itu dampak positif maupun dampak negatif. Dampak juga bisa merupakan proses lanjutan dari sebuah pelaksanaan pengawasan internal. Seorang pemimpin yang handal sudah selayaknya bisa memprediksi jenis dampak yang akan terjadi atas sebuah keputusan yang akan diambil.

Antman (2012) mengungkapkan bahwa proses orang tua atau anggota keluarga menjadi buruh migran memiliki dampak, baik positif dan atau negatif. Dampak positif lebih berkonotasi pada dimensi ekonomi karena orang tua dapat mengirimkan remitan dari pendapatannya bekerja di luar negeri. Remitan tentu menjadi salah satu alasan yang membuat orang tua ingin mendapatkan selisih gaji yang lebih besar dengan bekerja di luar negeri. Di samping orientasi ekonomi, alasan sosio-kultural juga menjadi faktor pendorong buruh melakukan migrasi internasional. Prestise dan status sosial akan terangkat seiring dengan perbaikan ekonomi rumahtangga buruh migran, situasi ini saling berkaitan satu sama lainnya.

Tidak dapat dielakan dampak negatif yang akan dihadapi keluarga dalam tumbuh kembang anak dari proses orang tua melakuka migrasi internasional karena mencari atau bekerja di luar negeri.

\section{Konsep Anak Dalam Filosofi Islam}

a) Anak merupakan anugerah

Anak merupakan anugerah dari Tuhan Yang Maha Kuasa, sebagaimana disebutkan dalam Alquran Surat AlAn'am, ayat 84:

"dan kami telah anugerahkan Ishak dan Ya'qub kepadanya. Kepada keduanya masing-masing telah kami beri petunjuk; dan kepada Nuh sebelum itu (juga) telah Kami beri petunjuk dan kepada sebagian dari keturunannya (Nuh), yaitu Daud, Sulaiman, Ayyub, Yusuf, Musa, dan Harun. Demikianlah kami member balasan kepada orang-orang yang berbuat baik."

Konsep-konsep semakna juga termaktub dalam: Q.Sal-Anbiya: 72, Q.S . al-Ankabut : 27, Q.S Ibrahim: 39, dan Q.S al-Furqon: 74 .

Anak sebagai anugerah cenderung menunjukan aksentuasi makna positif (baik) yakni anak-anak (keturunan) adalah sebagai penyejuk hati dan hadiah terindah dari Allah Swt kepada pasangan suami isteri.

b) Anak sebagai amanah

Kehadiran anak di samping sebagai anugerah juga merupakan amanah dari Allah kepada orang tua dengan cara membesarkan dan mendidik agar kelak mereka menjadi generasi yang berkualitas. Sebagaimana disebutkan dalam Q.S alAnfal: 27 :

"hai orang-orang yang berima, janganlah kami mengkhianati Allah dan Rasul (Muhammad) dan (juga) janganlah kamu mengkhianati amanat-amanat yang dipercayakan kepadamu, sedang kamu mengetahui."

Diperkuat dengan H.R Al-Bukhori yang menyatakan:

"jika amanah itu disia-siakan, tunggulah saat kehancuran.”

Sehingga dapat disimpulkan menyia-nyiakan anak seperti tidak memelihara atau membesarkan anak dengan baik begitu juga tidak mau mendidik secara serius, sama artinya dengan tidak bertanggung jawab terhadap anak yang telah dianugerahkan kepada orang tua. 


\section{Konsep Hak Anak}

Sebagaimana telah ditetapkan dalam Undang-Undang Nomor 23 Tahun 2002 Tentang Perlindungan Anak (UUPA) perlindungan terhadap anak dalam empat hak dasar anak yang sejalan dengan Konvensi Hak Anak PBB (The Convention On The Rights Of The Child), pasal 1 sebagai berikut:

1) Anak adalah seseorang yang belum berusia 18 (delapan belas) tahun, termasuk anak yang masih dalam kandungan.

2) Perlindungan anak adalah segala kegiatan untuk menjamin dan melindungi anak dan hak-haknya agar dapat hidup, tumbuh, berkembang, dan berpartisipasi, secara optimal sesuai dengan harkat dan martabat kemanusiaan, serta mendapat perlindungan dari kekerasan dan diskriminasi.

a) Hak hidup: terpenuhinya hak hidup anak ditandai dengan kepemilikan Akte kelahiran (pasal 5).

b) Hak tumbuh dan kembang: ditandai dengan anak dapat bersekolah, dapat melakukan aktivitas ibadah dan mendapatkan pelayanan kesehatan jika mereka sakit (pasal 6, 8, dan 9).

c) Hak berpendapat: ditandai dengan orang dewasa dapat dan membiasakan menerima dan memberikan kesempatan kepada anak untuk berpendapat dan RT ( pasal 10)

d) Hak mendapatkan Perlindungan dari Kekerasan: Dilindungi dari kekerasan dalam RT (pasal 15 dan 16).

\section{Metode Penelitian}

Jenis penelitian yang dilakukan oleh penulis adalah lapangan (field research) dengan menggunakan jenis penelitian campuran (mixed methodology). Mixed method menghasilkan fakta yang lebih komprehensif dalam meneliti masalah penelitian. Karena peneliti memiliki kebebasan untuk menggunakan semua alat pengumpul data sesuai dengan jenis data yang dibutuhkan. Tempat penelitian: Kec. Sususkan, Kec. Gebang, Kec. Babakan dan Kec. Kapetakan. Pengambilan sampel akan dilakukan secara purposif, yaitu 25 responden pada masing-masing empat kecamatan tersebut di atas. Data primer akan diperoleh dengan wawancara mendalam dengan responden terpilih. Diperkuat dengan catatan lapangan secara observasi, data sekunder akan diperoleh dari instansi yang relevan dari tingkat kabupaten sampe RT berupa keterangan dan catatan. Unit analisis dalam penelitian ini adalah orang tua dan anak buruh migran (keluarganya) di wilayah administratif Kabupaten Cirebon.

Pada hakekatnya teknik pengambilan sampel bertujuan untuk memperkecil kekeliruan generalisasi dari sampel ke populasi (Mantra, 2001). Berdasarkan pertimbangan tersebut, maka teknik purposive yang digunakan dalam penelitian ini. pada tahap awal dilakukan pengecekan data sekunder di Dinas Ketenagakerjaan untuk penentuan daerah kantong pengirim buruh migran di wilayah administratif Kabupaten Cirebon.

\section{E. Data dan Sumber Data}

Data kuantitatif diperoleh dari sumber data dari hasil wawancara terstruktur dan wawancara mendalam serta observasi lapangan terhadap responden dengan menggunakan kisi-kisi pertanyaan (Mantra, 2001). Analisis data disesuaikan dengan sifat data, data primer yang bersifat kuantitatif disajikan dalam bentuk data sedangkan yang bersifat kualitatif dengan cara analisis isi (Mantra, 2001). Variabel yang akan diteliti meliputi: karakteristik buruh migran, 
demografis, sosial dan ekonomi. Riwayat migrasi, implementasi 4 (Empat) hak dasar anak buruh migran dan regulasi dengan hak dan perlindungan anak buruh migran.

Data dalam penelitian ini terbagi menjadi dua kategori, pertama data kuantitatif yang diperoleh dengan daftar pertanyaan yang diajukan kepada informan dan responden sebagaimana terdapat pada tabel di atas. Sedangkan data kualitatif diperoleh melalui pertanyaan mendalam terhadap jawabanjawaban responden sehingga akan tergambar fenomena di balik jawaban kuantitatif yang telah disampaikan.

\section{F. Hasil dan Pembahasan}

\section{a. Karakteristik Buruh Migran}

\section{Karakteristik Sosial Dan Demografi}

Memahami karakteristik sosial dan demografi para buruh migran penting agar tergambar latar pemasalahan, khususnya berkaitan dengan profil buruh migran dan situasi yang melingkupinya. Fenomena permasalahan sosial bukan merupakan kausalitas tunggal, alih-alih di dalamnya akan karakteristik buruh migran dalam penelitian ini, sebagai berikut:

a) Jenis kelamin

Laporan tentang proposal penduduk yang pergi ke luar negeri sebagai buruh migran berdasarkan jenis kelamin menunjukan perempuan lebih besar dibandingkan dengan laki-laki, 84 persen dari daripada 16 persen. Angka tersebut menggambarkan proporsi nasional pada tahun 2014 di mana perempuan (57 persen) lebih besar daripada laki-laki (43 persen) sebagai buruh migran (Puslitbanginfo BNP2TKI, 2015).

b) Usia

Dari usia buruh migran di wilayah penelitian didapati proporsi tersebar yaitu 47 persen pada keompok 30 - 39 tahun. Kondisi ini tentu sangat lumrah karena usia produktif dan matang dalam lapangan kerja. Meskipun perlu diingat bahwa penggambaran tersebut tidak mempresentasikan kualitas karena umumnya mereka terserap pada sektor domestik sebagai pembantu rumah tangga dan buruh di pabrik atau perkebunan.

c) Pendidikan

Pendidikan merupakan faktor dominan kualitas sumberdaya manusia. Karena dengan pendidikan daya nalar dan kompetensi personal individu dapat meningkat. Dengan pendidikan daya adaptasi seseorang terhadap lingkungan dan kondisi baru akan lebih cepat. Demikian juga kemungkinan dapat memahami dan mencari solusi suatu permasalahan dapat dilakukan dengan baik.

Berdasarkan data lapangan menunjukan kualitas sumberdaya manusia tenaga kerja buruh migran cukup rendah sebagai berikut: proporsi terbesar pendidikan buruh migran dalam penelitian ini adalah lulusan Sekolah Dasar (SD) yaitu 53\%. Disusul lulusan SMP dengan proporsi 35 persen, lulusan SMA 9 persen dan 1 persen saja lulus pendidikan Diploma.

Hal ini tentu berpotensi menjadi permasalahan serius di Negara tujuan karena posisi tawar buruh migran kita sangat rendah, bahkan sangat memungkinkan menjadi objek eksploitasi perusahaan jasa tenaga kerja sebelum mereka benar-benar bekerja. Bahkan terdapat 2 orang yang tidak sekolah. Potensi yang mungkin terjadi di lapangan adalah mereka bekerja secara ilegal atau menggunakan dokumen palsu. Akan tetapi bukan pada tempat nya hal tersebut dibahas oleh peneliti.

d) Status perkawinan

Buruh migran dengan status nikah mendominasi hasil penelitian ini dengan proporsi 81 persen disusul dengan status 
janda atau duda 14 persen berikutnya status pisah 5 persen. Status perkawinan buruh migran akan berkolerasi dengan kebutuhan ekonomi keluarga hal ini menjadi alasan perempuan masuk ke sektor publik meskipun pada akhirnya tetap di dalam jenis atau karakteristik pekerjaan domestik.

e) Status dalam rumahtangga

Buruh migran dengan status pasangan Kepala RT mendominasi hasil penelitian ini, dengan proporsi 63 persen disusul dengan status pasangan sebagai anggota RT 26 persen berikutnya status anggota RT 11 persen. Status perkawinan akan berkolerasi dengan kebutuhan ekonomi keluarga hal ini menjadi alasan perempuan masuk ke sektor publik meskipun pada akhirnya tetap di dalam jenis atau karakteristik pekerjaan domestik.

Data tersebut menggambarkan beban dan tanggung jawab buruh migran dalam lingkup keluarga yang pada akhirnya akan berpengaruh pada kebutuhan ekonomi yang harus dipenuhi. Karena data hasil riset ini didominasi oleh buruh migran perempuan tentu implikasi status pasangan sebagai Kepala Rumahtangga yang dominan.

\section{Karakteristik Ekonomi}

Penggambaran karakter ekonomi buruh migran diharapkan akan semakin memperjelas kolerasinya dengan tingkat kebutuhan dan orientasi bekerja ke luar negeri. Karakterstik ekonomi meliputi data, sebagai berikut :

a) Sumber Pendapatan Rumahtangga

Proporsi terbesar sumber pendapatan rumahtangga buruh migran dalam penelitian ini adalah gabungan antara remitan (kiriman hasil kerja di Luar Negeri), pendapatan dan sumber lainnya sebesar 57 persen. Termasuk pendapatan gabungan adalah pendapatan dari remitan, pasangan dan lain-lainnya (bantuan dari orang tua, anak dan pendapatan dari sewa). Kemudian sumber pendapatan utama dari remitan sebesar 34 persen, dan pendapatan utama dari pasangan sebesar 2 persen. Terdapat 7 persen menjawab tidak tahu, hal terjadi karena buruh migran baru bekerja dan belum mendapatkan kiriman dari hasil kerja di luar negeri. Sebagian yang mengungkapkan bahwa pendapatan dari kerja sudah dipotong oleh yayasan pengirim jasa tenaga kerja ke luar negeri.

b) Jumlah remitan

Seberapa besar remitan yang diterima buruh migran menjadi gambaran betapa selisih jumlah pendapatan dari hasil mereka bekerja di luar negeri menjadi daya tarik tersendiri sehingga mereka berduyun-duyun ingin mengadu nasib ke luar negeri.

Hasil pengiriman uang kerja dari luar negeri merupakan daya tari para buruh migran untuk mengadu nasib ke negeri orang. Berdasarkan data lapangan proporsi tersebar remitan adalah pada rentang 1 juta s.d 2,9 juta sebesar 43 persen. Berikutnya disusul besaran remintan antara 3 juta s.d 4,9 juta sebesar 34 persen. Berturut-turut berikutnya besaran remitan di atas 5juta dengan proporsi 12 persen, dibawah 9999,999 dengan proporsi 1 persen dan 10 persen belum mendapatkan remitan karena pada sebagian besar mereka baru menjadi buruh migran di luar negeri.

Selisih besaran upah antara di dalam negeri dan di luar negeri nampaknya benar-benar menadi faktor penarik para buruh migran untuk bekerja di luar negeri dengan mengesampingkan potensi yang akan mereka hadapi kelak.

c) Pendapatan Rumahtangga

Permasalahan pendapatan yang rendah dan kemiskinan merupakan dua terminologi utama dalam pembangunan ekonomi yang saling pengaruh 
mempengaruhi. Karena pendapatan yang rendah mengindikasikan kemiskinan dengan segala budaya kemiskinan yang melingkupinya.

Berikutnya adalah berapa besar pendapatan RT buruh migran sehingga kerapkali ekonomi menjadi alasan utama buruh bekerja ke luar negeri. Pendapatan di sini merupakan akumulasi semua masukan finansial yang diperoleh keluarga buruh migran, baik dari remitan, pendapatan dari pasangan, dan sumber pendapatan lainnya. Termasuk ke dalam sumber pendapatan lainnya adalah: bantuan dari orang tua, bantuan dari anak yang sudah bekerja, pendapatan dari hasil sewa.

Proporsi terbesar jumlah pendapatan rumahtangga buruh migran pada kisaran 1 juta s.d 2,9 juta sebesar 34 persen. Berikutnya adalah rumahtangga dengan pendapatan 3 juta - 4,9 juta dengan proporsi 33 persen, rumahtangga dengan pendapatan diatas 5 juta dengan proporsi 24 persen dan terakhir rumahtangga dengan pendapatan kurang dari 1 juta dengan proporsi 9 persen.

Gambaran dari data tersebut mengindikasikan bahwa kondisi ekonomi para buruh migran dalam situasi masih di bawah standar kehidupan yang memadai, akan tetapi berdasarkan informasi dari beberapa keluarga buruh migran mengatakan bahwa pendapatan rumahtangga akan meningkat seiring dengan semakin lama mereka bekerja di luar negeri dari besaran remitan yang dikirimkan.

d) Pengeluaran Rumahtangga

Pengeluaran rumahtangga merupakan salah satu indikator yang dapat memberikan gambaran keadaaan kesejahteraan masyarakat. Tingkat pengeluaran terdiri atas dua komponen, yaitu pengeluaran untuk makanan dan bukan makanan. Tingkat kebutuhan terhadap dua komponen tersebut pada dasarnya berbeda-beda. Dalam kondisi pendapatan terbatas, kebutuhan makanan didahulukan, sehingga pada kelompok masyarakat berpendapatan rendah akan terlihat bahwa sebagian besar pendapatannya digunakan untuk membeli makanan. Seiring dengan peningkatan pendapatan, maka lambat laun akan terjadi pergeseran pola pengeluaran, yaitu penurunan porsi pendapatan yang dibelanjakan untuk makanana dan pengingkatan porsi pendapatan yang dibelanjakan untuk komponen bukan makanan.

Sedangkan pengeluaran rumahtangga buruh migran pada penelitian ini lebih dititik beratkan pada pengeluaran pokok, seperti makanan, pendidikan dan kebutuhan dasar lainnya.

Proporsi pengeluaran terbesar ada pada kelompok besaran antara 1 juta s.d 2,9 juta per bulan sebesar 65 persen dan diikuti besaraan 3 juta s.d 4,9 juta per bulan sebesar 20 persen, kurang dari 999,999 sebesar 14 persen dan 1 persen dengan pengeluaran di atas 5 juta. Meskipun demikian ada catatan tentang perubahan pola pengeluaran untuk kasus beberapa rumah tangga yang cenderung lebih dominan untuk konsumsi non makanan.

\section{b. Pola Pekerja Migrasi}

Memahami pola migrasi terkait permasalahan ketenagakerjaan diharapkan akan tergambar pola relasi antara kondisi sosial ekonomi dan orientasi bekerja ke luar negeri para responden. Di samping itu diharapkan tergambar pula keterkaitan semua latar tersebut dengan implementasi hak dan pelindungan anak buruh migran. Berikut akan dipaparkan pola migrasi responden dalam penelitian ini, sebagai berikut: 


\section{Lama bekerja}

Lama bekerja buruh migran adalah lamanya waktu (durasi) saat ini (yang sedang dijalani) para responden di mana mereka bekerja di luar negeri. Sebagai berikut:

Proporsi terbesar adalah buruh migran sedang menjalani masa kerja antara 1 tahun s.d. $<3$ tahun sebanyak 47 persen, kemudian 18 persen untuk masa kerja antara 3 tahun s.d $<5$ tahun. Dari gambaran lama kerja para responden untuk masa moderat menunjukan proporsi yang dominan hal ini mengandung arti stabilitas remitan yang dikirimkan para buruh migran kepada keluarganya di rumah sudah cukup baik. Terdapat juga proporsi 21 persen baru menjalani kurang dari 1 tahun dan 14 persen telah menjalani lebih dari 5 tahun.

\section{Negara Tujuan}

Lama bekerja buruh migran adalah lamanya waktu (durasi) saat ini (yang sedang sijalani) para responden di mana mereka bekerja di luar negeri. Taiwan menjadi Negara tujuan para buruh migran dengan proporsi tertinggi, sebanyak 44 persen responden memilih Taiwan sebagai tempat kerja mereka. Ada yang unik atas pilihan tersebut, karena telah mengubah kebiasaan negara tujuan yang selama ini biasa menjadi langganan para buruh migran.

Data dari BNP2TKI per 2013 menempatkan Malaysia menjadi negara tujuan para buruh migran besar 150 ribu orang, disusul Taiwan sekitar 84 ribu orang dan Saudi Arabia sekitar 45 ribu orang.

Berdasarkan hasil wawancara beberapa responden didapati bahwa besaran upah menjadi alasan mereka memilih Taiwan sebagai negara tujuan untuk bekerja. Hal dperkuat dengan bukti selebaran penawaran kerja dari salah satu perusahan jasa TKI yang tersebar di beberapa tempat, seperti di angkutan umum, seperti gambar leaflet di bawah ini.

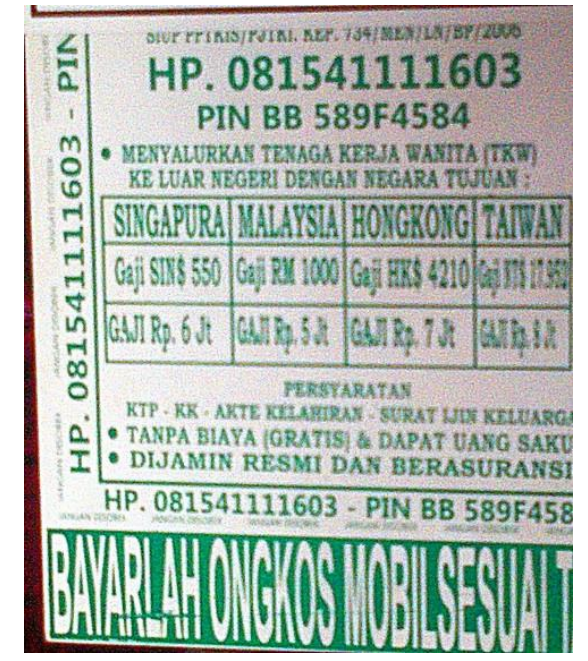

Berdasarkan informasi yang tertera dalam selebaran tersebut diungkapkan bahwa upah pekerja di Taiwan paling tinggi 8 juta per bulan. Berturut-turut berikutnya Hongkong 7 juta rupiah, Singapura 6 juta rupiah dan Malaysia 5 juta rupiah. Hal penting lainnya bahwa yang dicari atau yang ditawarkan untuk bekerja adalah perempuan bukan laki-laki. Hal ini berkaitan dengan jenis pekerjaan yang terbesar diserap di Negara tujuan adalah sebagai pembantu rumahtangga. 3. Pengalaman Sebagai Buruh Migran

Data tentang pengalaman sebagai buruh mihran yaitu memprtanyakan tentang sudah berapa kali buruh migran atau bekerja ke luar negeri. Data pengalaman berasosiasi dengan kontrak kerja sebagai tenaga kerjaa ke luar negeri. Informasi tentang pengalaman sebagai buruh migran penting karena berkaitan dengan orientasi bekerja ke luar negeri.

Antusias masyarakat untuk menjadi buruh migran bekerja ke luar negeri masih cukup tinggi. Hal ini dibuktikan dengan proporsi 36 persen adalah buruh migran baru (baru 1 kali) dan bahkan 36 persen sudah 2 kali (bisa pada tujuan Negara yang sama atau memperpanjang kontrak 
atau pindah ke Negara baru). Buruh migran yang beberapa kali bekerja ke luar negeri sangat potensial merupakan penggambaran orientasi bukan hanya karena alasan ekonomi. Dengan beberapa kali atau terus memperpanjang kontrak sebagai tenaga kerja ke luar negri ada asumsi pemenuhan kebutuhan berikutnya. 4. Alasan Bekerja Sebagai Buruh Migran

Alasan bekerja sebagai buruh migran salah satu poin penting mengapa individu memutuskan untuk melakukan pekerjaan dengan risiko tinggi, karena hal tersebut menjadi faktor utama pendorong melakukan migrasi.

Alasan keluarga merupakan proporsi terbesar para buruh harus bekerja ke luar negeri sebesar 50 persen. Alasan keluarga sebenarnya sangat mendekati dan bersentuhan langsung dengan ekonomi, nyaris sulit dibedakan, di dalamnya meliputi; untuk menghidupi keluarga, untuk membiayai pendidikan anak, untuk hidup mandiri, ingin seperti kehidupan tetangga, ingin memiliki rumah sendiri, dan sebagai penanggung jawab keluarga. Alasan keluarga merupakan manifestasi budaya atau latar sosial yang menjadi latar belakang pekerja bekerja ke luar negeri. Sedangkan responden yang mengungkapkan secara gamblang bekerja ke luar negeri karena alasan ekonomi terdapat proporsi 44 persen. Terakhir karena alasan kerja sebesar 6 persen yaitu; ingin cari pengalaman kerja, lebih besar gajinya, lebih mudah kerjanya dan diajak oleh saudara ke luar negeri.

\section{c. Implementasi Hak dan Perlindungan Anak Buruh Migran}

Pada tanggal 25 Agustus 1990

Presiden Suharto telah menandatangani Surat Keputusan Presiden Nomor 36 Tahun 1990 Tentang Pengesahan Convention On The Rights Of The Child (Konvensi Hak-Hak Anak PBB). Ini mengandung arti bahwa pemerintah harus mengakui dan sesegera mungkin mengadopsi peraturan yang ada dalam konvensi dan melaksanakannya dalam kehidupan berbangsa dan bernegara. Keseriusan negara Indonesia diwujudkan dengan lahirnya Undang Undang Nomor 23 Tahun 2002 Tentang Perlindungan Anak (UUPA) dan diperbaharui dengan Undang Undang Nomor 35 Tahun 2014 Tentang Perubahan Undang Undang Nomor 23 Tahun 2002 Tentang Perlindungan Anak.

Pada pasal 1 UUPA dijelaskan bahwa:

1) Anak adalah seseorang yang belum berusia 18 (delapan belas) tahun, termasuk anak yang masih dalam kandungan.

2) Perlindungan anak adalah kegiatan untuk menjamin dan melindungi anak dan hak-haknya agar dapat hidup, tumbuh, berkembang, da berpartisipasi, secara optimal sesuai dengan harkat dan martabat kemanusiaan, serta mendapat perlindungan dari kekerasan dan diskriminasi.

Deskripsi tentang empat hak dasar anak telah ditetapkan dalam pasal 4 UUPA meliputi : Setiap anak berhak untuk dapt 1) hidup, 2) tumbuh, berkembang, dan 3) berpartisipasi secara wajar sesuai dengan harkat dan martabat kemanusiaan, serta 4) mendapat perlindungan dari kekerasan dan diskriminasi.

Dalam penelitian ini representasi darib imlementasi hak dan perlindungan anak buruh migran, sebagai berikut:

\section{Hak Identitas}

Pasal 5 UUPA menyebutkan bahwa setiap anak berhak atas suatu nama sebagai identitas diri dan status kewarganegaraan. Akta kelahiran adalah manifestasi dari hak hidup anak, pengakuan sosial sebagai warga negara 
dan warga masyarakat. Hasil survey atas kepemilikan akte kelahiran anak buruh migran sebagai berikut.

Proporsi terbesar anak buruh migran telah memiliki akte kelahiran. Sebenarnya angka tersebut lebih baik dari angka kepemilikan akte kelahiran tingkat di Provinsi Jawa Barat sekitar 80 persen.

Hanya 11 persen saja yang tidak memiliki akte kelahiran dengan alasan biaya yang mahal, jarak yang jauh, merasa sulit mengurusnya atau malas dan menganggap tidak perlu. Namun sebagai catatan dari proporsi anak yang memiliki akta kelahiran tersebut, terdapat sekitar 15 persen kepemilikannya hanya disampaikan secara verbal.

\section{Hak Melaksanakan Aktivitas}

Keagamaan (Sholat dan Mengaji)

Dalam Pasal 6 UUPA disebutkan bahwa setiap anak berhak untuk beribadah menurut agamanya, berpikir, dan berekspresi sesuai dengan tingkat kecerdasan dan usianya, dalam bimbingan orang tua. Hak tersebut merupakan bagian dari hak tumbuh kembang anak secara wajar dan tentu harus melalui bimbingan dan pendampingan dari orang tua dan orang dewasa di sekitarnya. Dalam penelitian ini yang dimaksud hak melaksanakan aktivitas keagamaan (yaitu melakukan sholat wajib lima waktu dan belajar mengaji). Apakah orang tua mendukung, memotivasi dan memberikan bimbingan serta pendampingan anak melakukan aktivitas tersebut?

Hasil survey atas hak untuk melaksanakan aktivitas keagamaan pada anak buruh migran adalah : terdapat 80 persen anak buruh migran tetap mendapatkan motivasi, bimbingan dan pendampigan untuk menjalankan aktivitas keagamaan, meskipun ketiadaan ibu atau bapak yang sedang bekerja ke luar negeri. Sedangkan terdapat 20 persen keluarga kurang peduli, tidak mampu, dan menyerah karena anak susah diatur, disuruh dan diajak untuk sholat atau mengaji. Ada juga karena usia anak masih di bawah umur jadi mereka mentoleransi anak-anak untuk tidak atau belum sholat dan mengaji.

Pada fase usia anak tumbuh dan berkembang seharusnya orang tua, keluarga atau pihak yang memiliki tanggung jawab lebih serius melakukan proses parenting pada mereka. Karena situasi kejiwaan dan psikologis mereka selalu ingin mencoba, ingin tahu dan ingin diperhatikan. Keberhasilan orang tua menenamkan nilai-nilai positif pada anak menjadikan mereka memiliki pengalaman pembelajaran yang berbekas untuk proses sosialisasi mereka dalam pergaulan di dalam masyarakat.

\section{Hak Memperoleh Pelayanan \\ Kesehatan \\ Dalam Pasal 8 UUPA disebutkan} bahwa setiap anak berhak memperoleh pelayanan kesehatan dan jaminan sosial sesuai dengan kebutuhan fisik, mental, spiritual dan sosial. Hak tesebut merupakan bagian dari hak tumbuh kembang anak secara wajar karena makna tumbuh lebih ke kondisi fisik atau jasmani. Dalam penelitian ini yang dimaksud hak memperoleh pelayanan kesehatan adalah pilihan orang tua atau keluarga ketika anak buruh migran menderita sakit, pelayanan kesehatan seperti apa yang diberikan kepada mereka.

Dara hasil survey menggambarkan kesadaran masyarakat cukup tinggi dalam penggunaaan layanan kesehatan modern. Layanan kesehatan modern bukan lagi barang mewah bagi masyarakat dewasa ini. sejak digulirkannya program BPJS Kesehatan oleh pemerintah, dengan segala permasalahannnya masyarakat didorong untuk dapat memanfaatkan layanan kesehatan modern, mulai dari tingkat dasar, puskesmas, dokter pribadi atau 
dokter praktek, bidan, rumah sakit sesuai tingkatannya. Terdapat 94 persen orang tua atau keluarga menggunakan layanan kesehatan modern ketika anak buruh migran sakit. Puskesmas menjadi pilihan utama mereka, kemudian bidan, dan dokter praktek.

Penggunaan pengobatan alternatif oleh masyarakat memang diakui masih menjadi pilihan ketika anak sakit. Berturut-turut pilihan itu adalah beli obat di warung, pake obat atau ramuan tradisional, dan langsung beli obat di apotek. Hanya terdapat 6 persen keluarga anak buruh migran menggunakan pengobatan alternatif ketika anak-anak sakit.

\section{Hak Pendidikan}

Dalam Pasal 9 ayat (1) Undang Undang Perlindungan Anak disebutkan bahwa setiap anak berhak memperoleh pendidikan dan pengajaran dalam rangka pengembangan pribadinya dan tingkat kecerdasannya sesuai dengan minat dan bakatnya. Hak tersebut merupakan bagian dari hak tumbung kembang anak secara wajar terutama aspek perkembangan rohani dan intelektual anak. Dalam penelitian ini yang dimaksud hak memperoleh pendidikan adalah apakah anak di sekolah atau tidak oleh orang, baik pada pendidikan forman ataupun non formal. Bagaimana perhatian orang tua dan keluarga buruh migran terhadap pendidikan anak.

Dewasa ini kesadaran masyarakat terhadap pendidikan sudah tidak diragukan lagi. Hasil survey menunjukkan 82 persen anak buruh migran terpenuhi hak pendidikan mereka. Hanya ada 18 persen saja yang tidak atau belum besekolah. Alasan mereka tidak bersekolah sebagian besar karena mau bekerja dan mereka merasa sudah tidak mampu lagi berfikir.
Penelitian juga belum menelaah lebih lanjut kualitas pendidikan yang dijalani anak-anak buruh migran. Permasalahan apa saja yang dihadapi mereka dalam menjalani proses pembelajaran, seperti apa prestasi pendidikan mereka dengan ketiadaan salah stau orang tua mereka, khsususnya ibu. Diperlukan penelitian dengan fokus perkembangan psikologi dan adaptasi sosial anak buruh migran dengan tujuan untuk mencari formulasi atas permasalahan yang dihadapi agar tumbuh kembang mereka tertuntaskan secara optimal.

\section{Hak Berpendapat}

Dalam pasal 10 Undang Undang Perlindungan Anak disebutkan bahwa setiap anak berhak menyatakan dan didengar pendapatnya, menerima, mencari, dan memberikan informasi sesuai dengan tingkat kecerdasan dan usianya demi pengembangan dirinya sesuai dengan nilai-nilai kesusilaan dan kepatutan. Dalam penelitian ini yang dimaksud hak berpendapat adalah sejauhmana orang tua atau keluarga anak buruh migran mau mendengarkan, mengajak bicara dan memberikan informasi tentang keadaan orang tua mereka, situasi sosial di lingkungan sekitar anak tersebut tinggal.

Bukanlah hal yang mudah mau mendengarkan anak berbicara dan mengungkapkan pendapat mereka, persepsi orang dewasa sangat diskriminatif terhadap anak-anak karena mereka dianggap tidak memiliki kapasitas untuk berpendapat dan menyampaikan idea atau gagasan. Keadaan yang menguntungkan bagi anak buruh migran di Kabupaten Cirebon karena dari hasil survey diperoleh data 84 persen orang tua atau keluarga mau mmendengarkan suara mereka. Hanya 16 persen saja orang tua yang mengungkapkan bahwa anak-anak 
tidak perlu banyak bertanya, anak sebaiknya ikuti saja apa kata orang tua. Sedikit dari mereka mengungkapkan bahwa yang penting buat anak kebutuhan mereka dapat dipenuhi oleh orang tua. Tugas anak adalah belajar yang tekun agar kelak dapat bekerja dan membantu orang tua.

\section{Hak Perlindungan}

Pasal 13 Undang Undang Perlindungan Anak menyebutkan bahwa (1) setiap anak selama dalam pengasuhan orang tua, wali, atau pihak lain manapun yang bertanggung jawab atas pengasuhan, berhak mendapatkan perlindungan dari perlakuan: a.) diskriminasi, b.) eksploitasi, baik ekonomi maupun seksual, c.) penelantaran, d.) kekejaman, kekerasan dan penganiayaan, e.) ketidakadilan, dan f.) perlakuan salah lainnya. Dalam penelitian ini yang dimaksud hak perlindungan adalah orangtua dan/atau keluarga anak buruh migran, apakah melakukan kekerasan dalam proses parenting dalam keseharian di rumah?

Kekerasan anak banyak terjadi dari rumah, hal ini kerapkali dipicu oleh kondisi ekonomi rumahtangga yang terlilit belenggu kemiskinan. Pada dasarnya masalah ekonomi keluarga terdiri atas banyak jenis, ada kekerasan pada isteri, perceraian, perebutan anak, kekerasan pada anak dan lain-lain. Akan tetapi, sebagaimana kekerasan dalam rumahtangga, kekerasan pada anak merupakan kasus terselubung karena orang tua kerap memandang kekerasan tersebut masuk wilayah domestik serta tidak memerlukan intervensi dari pihak luar bahkan intervensi hukum sekalipun (Suryadi, 2015).

Data hasil survey menunjukan 80 persen orang tua atau wali tidak melakukan kekerasan dalam proses parenting kepada anak buruh migran. Sebagian besar dari mereka mengungkapkan hanya menasehati ketika anak-anak tidak menurut atau bandel dalam kesehariannya. Sedangkan 20 persen orang tua atau wali melakukan kekerasan. Akan tetapi dari hasil wawancara mendalam dengan beberapa orang tua atau wali si anak, mereka hanya melakukan kekerasan ringan seperti mencubit dan menjewer. Mereka juga sebagian melakukan kekerasan verbal dengan memarahi anak yang sulit diatur atau membantah kepada orang tua.

\section{d. Persepsi Masyarakat tentang Perlunya Regulasi dan Implementasi Hak dan Perlindungan Anak Buruh Migran di Kabupaten Cirebon}

Berdasarkan pendapatan dan pernyataan para tokoh diatas, dapat disimpulkan bahwa permasalahan akan buruh migran memang memerlukan perhatian khusus melihat cakupan masalah tersebut cukup serius karena harus dihadapi oleh anak-anak yang merupakan generasi penerus bangsa. Menjadi hal yang miris jika anak yang kelak akan menjadi tulang pungggung bangsa tumbuh dengan tidak optimal karena ketiadaan pemberi dampingan utama proses tumbuh kembang mereka untuk mecari kerja ke luar negeri. Semua pihak baik pemerintah, non pemerintah, masyarakat dan keluarga harus mencurahkan segenap potensi yang dimiliki untuk bersinergi demi kepentingan terbaik anak.

Pemerintah harus proaktif dalam menghadapi permasalahan anak buruh migran karena pada masyarakat umumnya nilai yang tertanam terhadap permasalahan anak atau masalah keluarga lainnya termasuk kategori kausus domestik yang tabu jika diungkapkan di publik. Sehingga strategi model pendekatan dalam bentuk program atau intervensi lainnya harus bersinergi dengan elemen yang ada dalam masyarakat. 
Sehingga jangan sampai muncul anggapan negatif yang menyebabkan anak dan keluarga buruh migran enggan untuk terlibat dalam program-program solutif permasalahan anak buruh migran.

Berkaitan dengan regulasi khusus anak buruh migran, beberapa pihak nampaknya memandang tidak semestinya ada regulasi khusus karena Undang Undang Perlindungan Anak dirasakan sudah cukup memadai. Sehingga yang diperlukan adalah aturan-aturan di bawahnya yang bersifat teknis impelementatif terkait langsung permasalahan anak buruh migran. Sehingga komitmen kebijakan yang ramah dan pro anak harus menjadi perhatian bersama.

\section{G. Simpulan}

1. Secara umum, gambaran karakteristik buruh migran menunjukan latar belakang penduduk dengan karakteristi pergeseran rural ke urban. Berpikir pragmatis dan serba cepat, orientasi ekonomi dengan beberapa target peningkatan status sosial keluarga dalam masyarakat menjadikan buruh migran pilihan yang tepat. Latar belakang pendidikan yang rendah menjadikan buruh migran terserap pada sektor pekerjaan kasar, seperti : pembantu rumah tangga, perawat lansia atau anak dan pekerja perkebunan. Kesadaran tentang pendidikan anak, akses pada pelayanan kesehatan modern, pola keluarga kecil semakin meyakinkan para migran menyadari betul pergeseran nilai anak dari investasi menjadi biaya.

2. Kesadaran bahwa anak merupakan amanah Tuhan Yang Maha Esa dengan beberapa konsekuensi tanggung jawab orang tua untuk memenuhinya sudah terimplementasikan. Parameter impelementasi hak anak bisa dilihat dari proporsi yang besar atas pemenuhan hak dan perlindungan anak oleh orang tua (buruh migran) atau keluarganya. Meskipun masih banyak catatan berkaitan dengan kedalaman jawaban baik oleh orang tua, wali atau beberapa anak yang diwawacara.

3. Persepsi para tokoh masyarakat sebagian besar mengatakan bahwa perlunya perhatian dari pemerintah, keluarga, masyarakat dan semua pihak terhadap permasalahan dan hak dan perlindungan anak buruh migran. Dimulai dengan keseriusan pemerintah dalam megelola permasalahan buruh migran (Tenaga Kerja Indonesia) itu sendiri. Sebagian narasumber, tokoh masyarakat berkomentar tidak perlu adanya regulasi secara khusus untuk anak buruh migran. Akan tetapi cukup dalam tataran kebijakan dan program yang bersinergi dari semua stakeholder baik instansi maupun organisasi non pemerintah.

\section{H. Saran}

Dari fakta yang terkumpul dalam penelitian ini ada beberapa saran yang diajukan, sebagai berikut: pertama, perlu keseriusan dari berbagai kalangan khususnya pemerintah untuk membahas kembali kebijakan yang berkaitan dengan hak dan perlindungan anak buruh migran dalam bentuk peraturan pemerintah khususnya dalam implementasi programprogram yang pro anak. Kedua, peran semua kalangan termasuk tokoh masyarakat dan pihak-pihak yang terkait serta peran lembaga tinggi dalam bentuk penelitian, pengadaan database anak buruh migran dengan segala macam karakter, permasalahan dan potensi solusi lokal yang ada. Ketiga, penelitian lanjutan berkaitan dengan permasalahan yang fokus pada pemenuhan pertumbuhan dan perkembangan anak secara kualitatif. 


\section{Daftar Pustaka}

Al-QurannulKarim

Abdullah, Irwan. 2001. Masalah Peranan Kaum Perempuan Dalam Pembangunan Nasional. Reorientasi Kebijakan Kependudukan, Faturachman dan Agus Dwiyanto, (ed). Yogyakarta: PKK-Universitas Gajah Mada.

Antman, Francisca M. 2012. The Impact of Migration on Family Left Behind. IZA and Department of Economics University of Colorado at Boulder 256 UCB.

Briyant. John (2005), Chidren of International Migrants in Indonesia, Thailand, and Philippines: A Review of Evidence and Policies. Innocenti Working Paper No. 2005-05. Florence, UNICEF Innocenti Research Centre.

Brettell, C. B. "Theorizing Migration in Antropology. The Social Construction of Networks, Identities, Communities, and Globalscapes", in Brettell, C. (ed.). Migration Theory. London: Routledge, 2000.

Creswell, John W. Research Design: Qualitative, quantitave, and mixed method approaches.-2nd ed. Thousand Oaks, California 91320 : Sage Publication.

Demurger, Sylvie and $\mathrm{Xu}$, Hui. LeftBehind Children and Return Decision of Rural Migrant in China. IZA DP No. 7727, November 2013

Mantra, Ida Bagoes. 2001. Langkahlangkah Penelitian Survei, Usulan
Penelitian dan Laporan Penelitian. Edisi III. Yogyakarta:BPFG UGM.

Mantra, I. B. Dan Kasto. 1989. Penentuan Sampel. Metode Penelitian Survei, Masri Singarimbun dan Sofian Effendi, (ed). Jakarta: LP3ES.

Mustaqim, Abdul. 2006. Kedudukan Dan Hak-Hak Anak Dalam Perspektif AlQuran (Sebuah Kajian dengan Metode Tafsir Tematik). Musawa Jurnal Studi Gemder dan Islam. Vol. 4 No. 2 Bulan Juli, Halaman : 145-169.

Nainggolan, Togiaratua. Gender dan Keluarga Migran di Indonesia. Pusat Penelitian dan Pengembangan Kesejahteraan Sosial. Department Sosial RI. Diunduh pada Minggu, 2703-2016 dari website http://puslit.kemesos.go.id/upload/post/ files/e9e220b0cec949dd1d8db20ae145 2b57.pdf

Nasir, Mohammad (1999). Metode Penelitian. Ghalia Indonesia, Jakarta.

Pitoyo, Agus Joko dan Kiswanto, Eddy. 2012. Dampak Pengiriman Buruh Migran Perempuan ke Luar Negeri Terhadap Penurunan Fertilitas Dan Kesehatan Anak. BKKBN

Rozy Munir. 1981. Dasar-dasar Demografi. Jakarta : Lembaga Demografi Fakultas Ekonomi Universitas Indonesia.

Suryadi. 2015. Pemberdayaan Fungsi Keluarga (Tela'ah Terhadap Tren Angka Kekerasan pada Anak), Jurnal Orasi IAIN Syekh Nurjati CirebonVol. 6 No. 2 Desember 2015, ISSN : 2085-7357, hal. $49-62$. 
Triantoro, Bambang Wicaksono. Populasi 1999, X (2). Migrasi Legal Dan Ilegal Ke Malaysia Barat: Kasus Migrasi Internasional Di Pulau Lombok, Nusa Tenggara Barat.

Undang-Undang Nomor 4 Tahun 1979 Tentang Kesejahteraan Anak.

Undang-Undang Nomor 23 Tahun 2002 Tentang Perlindungan Anak.

Wardi Bachtiar, Meodologi Penelitian Ilmu Dakwah, (Jakarta: Logos, 1997).
World Bank. 2013, Migration and Development Brief 20. www.worldbank.org.id. Diakses pada 12 Desember 2016.

www.kbbi.web.id/

www.BNP2TKI.go.id

https://nasional.tempo.co/read/news/2011/ 05/03/173331889/hidup-susah-didalam-negeri-warga-terpaksa-migrasi 